Research Article

\title{
Conversion of Crude Glycerol from By-product Biodiesel into Bio-additive of Fuel through Acetylation Reaction based on Modified Zeolite Catalyst
}

\author{
Heny Dewajani*, Windi Zamrudy, Hadi Saroso, Satria Paramarta, Wahyudianto Mulya \\ Chemical Engineering Program, Politeknik Negeri Malang, Malang, Indonesia, 65141
}

\section{ARTICLE INFO}

Article History

Received 07 August 2019

Revised 29 October 2019

Available online 4 December 2019

*Email of author corresponding:

henyhp@gmail.com

\section{ABSTRACT}

Biodiesel is one of the alternative fuels produced from the transesterification reaction between triglycerides and alcohols with glycerol by-products. So far, the resulting crude glycerol has not been maximally utilized because of its low purity. So, it is necessary to purify glycerol before turning it into a more useful compound. The purified glycerol can be reacted with acetic acid within esterification reaction (acetylation process) using an acid catalyst to produce glycerol triacetate (triacetin). One of the uses of triacetin as an additive in gasoline and biodiesel. The purpose of this study is to utilize glycerol from byproducts from biodiesel production to bio-additive materials that can improve fuel quality and are environmentally friendly. The method used in this study begins with the purification of crude glycerol, modification of zeolite catalyst with impregnated of nickel metal followed by an acetylation reaction which held on temperature of $100^{\circ} \mathrm{C}$ for $60 \mathrm{~min}$. The experimental results are analyzed using base titration to determine the remaining unreacted acids and are applied as bioadditives by adding them to commercial fuels and measured the increasing octane numbers. The result shows that the reaction conversion increases with increasing mole ratio of reactants and catalysts with the best results in the mole ratio of acetic acid and glycerol is $9: 1$ and catalyst $5 \%$ by weight of acetic acid with a conversion of $66.02 \%$. As bio-additives the reaction product could increase the octane number of commercial fuel by 6.5 up to $8.5 \%$.

Keywords: glycerol, acetylation reaction, mofified zeolite, bio-additive

\section{Introduction}

The increasing production of biodiesel as biofuel in order to reduce the use of fossil fuels in which the supply is depletion, causing an increasing glycerol as a by-product of biodiesel production. In the process of making biodiesel also produced by-products in the form of glycerol by $10 \%$ from the results of biodiesel obtained. The percentage of these results can be predicted that by 2020, Indonesia will produce crude glycerol as a by-product of biodiesel as much as 0.42 million liters per year. Crude glycerol has not been utilized optimally because of its impurities such as water, residual catalysts and residual reactants so that the purification process needs to be done for getting the high purity glycerol. Crude glycerol which has been purified is a potential material to be converted into additive and environmentally friendly compounds. Therefore, it is necessary to study the method of purification and alternative uses. There are several alternatives to using glycerol to become a value-added material. One of them is processing glycerol into triacetin which can be used as a bioadditive for fuel $[1,2,3]$. The addition of a $10 \%$ triacetin to biodiesel can improve engine performance in all aspects [4].

Triacetin is widely used in the cosmetics industry and as an additive in fuels to improve fuel performance at low temperatures and its viscosity [1]. This additive is needed to increase the octane numbers and improve combustion efficiency in the engine. Tetraethyl Lead (TEL) is one of the chemicals that were often used as gasoline additives, but it 
turns out that TEL is not environmentally friendly because of the toxic nature of lead. Subsequently attempted to replace TEL additives with Methyl Tertiary Butyl Ether (MTBE), which is made from methanol and isobutylene with certain catalysts. However, it turns out MTBE also has carcinogenic properties and dissolves in water, so that if the premium with MTBE additives spills on the ground it will pollute the surrounding water sources. This condition encourages researchers to look for substitutes for environmentally friendly gasoline additives to substitute for MTBE and TEL.

The aims of this research are to purify the crude glycerol from the by-products of biodiesel production and to synthesis the purified glycerol through acetylation reaction into bio-additive fuel based on Ni/zeolite solid catalysts with various ratio of acetic acid to glycerol and percentage of catalyst to acetic acid. The use of zeolite solid catalysts is based on the advantages of heterogeneous catalysts that are easily separated from the reaction product and the ability to be reused. The innovations that are targeted to utilize the crude glycerol into triacetin as bio-additives of gasoline and biodiesel fuels using modified zeolite catalyst.

\section{Materials and Methods}

\subsection{Materials}

Materials used in the study were crude glycerol obtained from PT Wilmar (Gresik), acetic acid (glacial) $100 \%$ anhydrous for analysis (Merck), natural zeolite and $\mathrm{Ni}\left(\mathrm{NO}_{3}\right)_{2} \cdot 6 \mathrm{H}_{2} \mathrm{O}$ for analysis (Merck), phosphoric acid $85 \%$ (Merck), pro analysis glycerol (Merck) and $\mathrm{HCl} 37 \%$ (Merck).

\subsection{Catalyst Preparation}

Zeolite was soaked in $4 \mathrm{~N} \mathrm{HCl}$ solution (mass ratio of zeolite : $\mathrm{HCl}=1: 2$ ). The solution was put into a three-neck flask equipped with cooling reflux and magnetic stirrer. The solution was heated using a waterbath at temperature of $90^{\circ} \mathrm{C}$ for $3 \mathrm{~h}$. Zeolites were filtered and washed using aquadest. The formed catalyst was dried in an oven at $120^{\circ} \mathrm{C}$ for $2 \mathrm{~h}$. The catalyst was calcined at $600^{\circ} \mathrm{C}$ for $3 \mathrm{~h}$. The $4 \%(\mathrm{w} / \mathrm{w}) \mathrm{Ni}\left(\mathrm{NO}_{3}\right)_{2} \cdot 6 \mathrm{H}_{2} \mathrm{O}$ solution was impregnated into the zeolite suspension at $80^{\circ} \mathrm{C}$ and stirred for $3 \mathrm{~h}$ using a magnetic stirrer. The formed catalyst was dried in an oven at a temperature of $120^{\circ} \mathrm{C}$ for $3 \mathrm{~h}$. The catalyst was calcined at a temperature of $600^{\circ} \mathrm{C}$ for $3 \mathrm{~h}$.

The impregnated catalysts are tested using SEM analysis to see its morphology, XRD to identify the crystal structure and XRF to determine its chemical composition. Based on Figure 1 and 2, it can be seen that nickel metal has been scattered on the catalyst surface.

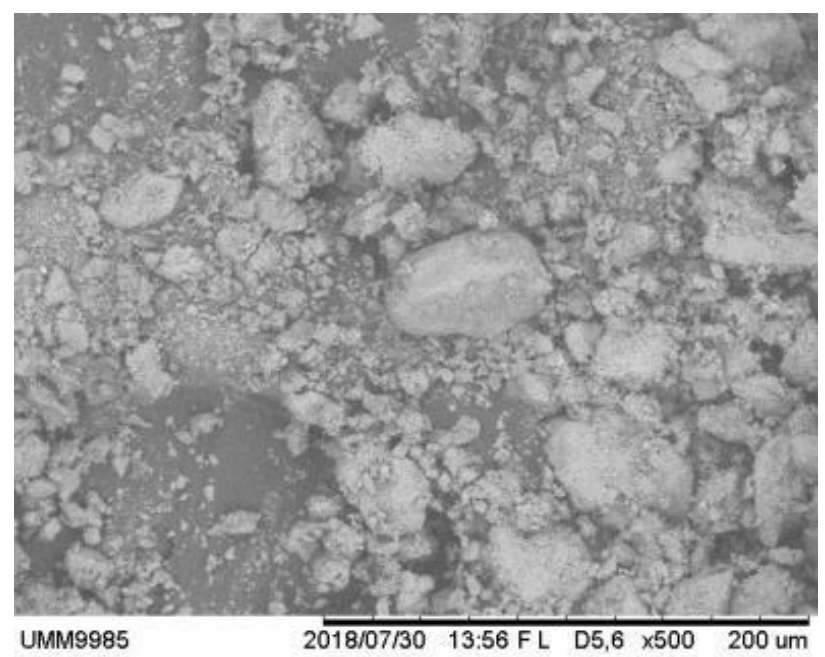

Figure 1. The morphology of zeolite catalyst using SEM analysis by 500 magnification.

From the XRD analysis, the diffractogram pattern in Figure 3 shows the main peak of zeolite expressed in $2 \theta$ is $26.5979^{\circ}$ has the same characteristics as mordenite zeolite from reference (Center for Diffraction Data (ICDD) 49-0924) on the peak of $2 \theta=26-27^{\circ}$ [5]. The presence of impregnated Ni metal is shown in value of $2 \theta$ at $43.2603^{\circ}$ [6]. Figure 3 shows that the zeolites modified with $\mathrm{Ni}$ metal have the highest peak at an angle of $26.61^{\circ}$ equal to the zeolite catalyst diffractogram. 


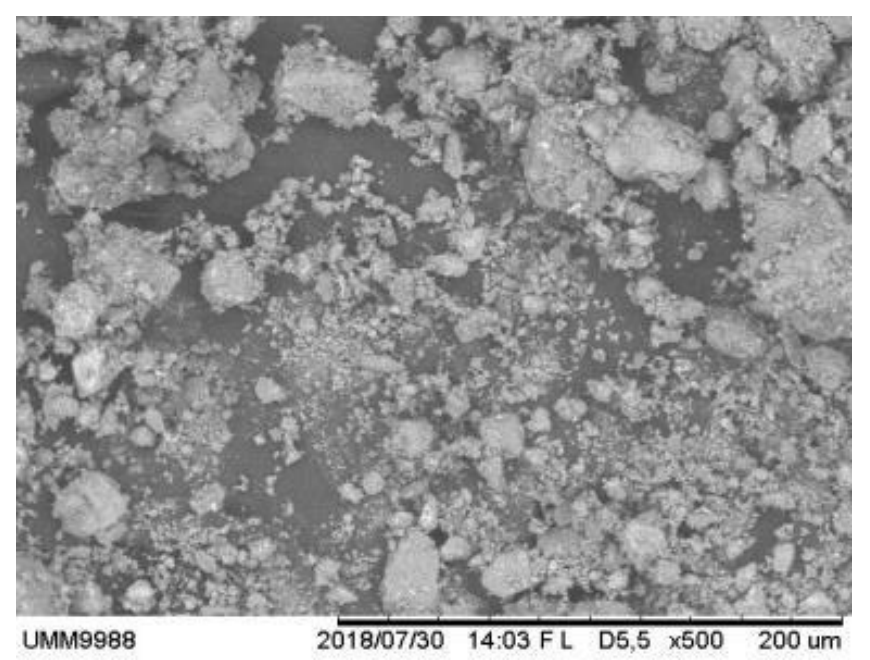

Figure 2. The morphology of $4 \%$ Ni/zeolite catalyst using SEM analysis by 500 magnification.

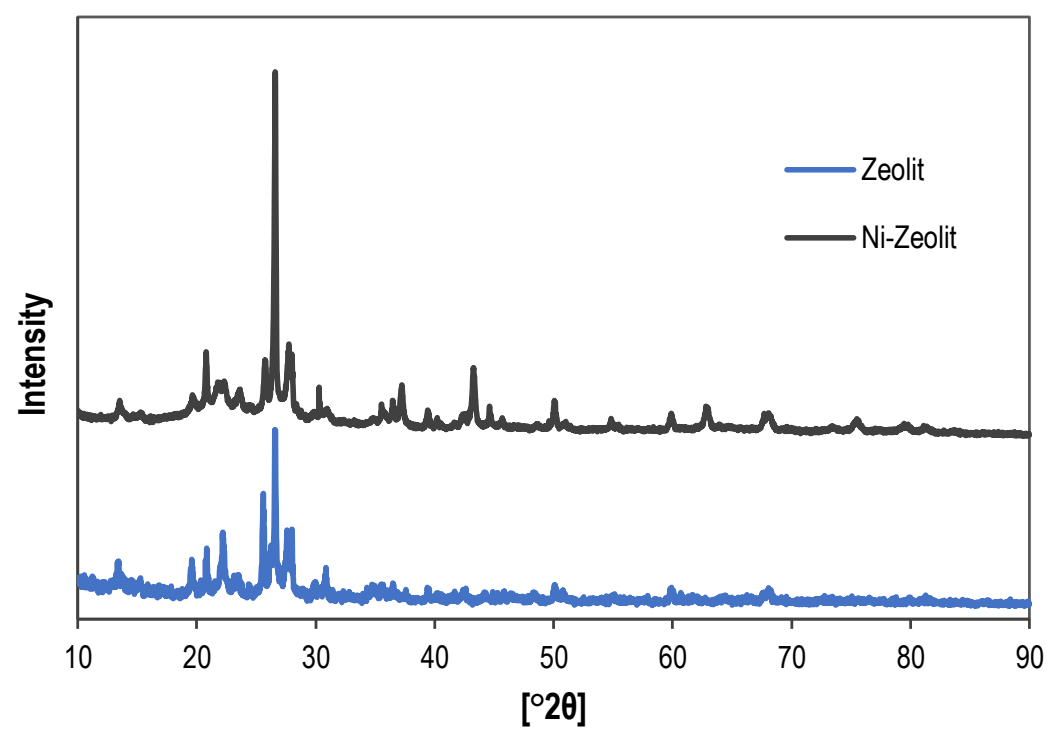

Figure 3. Diffractogram pattern of zeolite and Ni/zeolite.

Table 1. XRF Characterization of Ni/zeolite Catalysts

\begin{tabular}{cc}
\hline Elements & Weight (\%) \\
\hline $\mathrm{Al}$ & 2.00 \\
$\mathrm{Si}$ & 18.6 \\
$\mathrm{P}$ & 0.49 \\
$\mathrm{~K}$ & 3.45 \\
$\mathrm{Ca}$ & 1.75 \\
$\mathrm{~V}$ & 0.03 \\
$\mathrm{Cr}$ & 0.10 \\
$\mathrm{Mn}$ & 0.04 \\
$\mathrm{Fe}$ & 2.04 \\
$\mathrm{Ni}$ & 66.16 \\
\hline
\end{tabular}

This shows that the nickel metal impregnation process does not reduce the crystallinity of zeolites [7]. Figure 3 shows that the zeolites modified with $\mathrm{Ni}$ metal have the highest peak at an angle of $26.61^{\circ}$ equal to the zeolite catalyst diffractogram. This shows that the nickel metal impregnation process does not reduce the crystallinity of zeolites [7]. Figure 4 shows the spectrum of XRF analysis results and the composition of $\mathrm{Ni} /$ Zeolite can be seen in Table 1. The percentage 
of nickel in the catalyst shows that the nickel has been impregnated in the catalyst. The composition of $\mathrm{Si}$ and $\mathrm{Al}$ in $\mathrm{Ni} / z e o l i t e$ is $18.60 \%$ and $2.00 \%$ so that the ratio of $\mathrm{Si} / \mathrm{Al}$ is 9.3 .

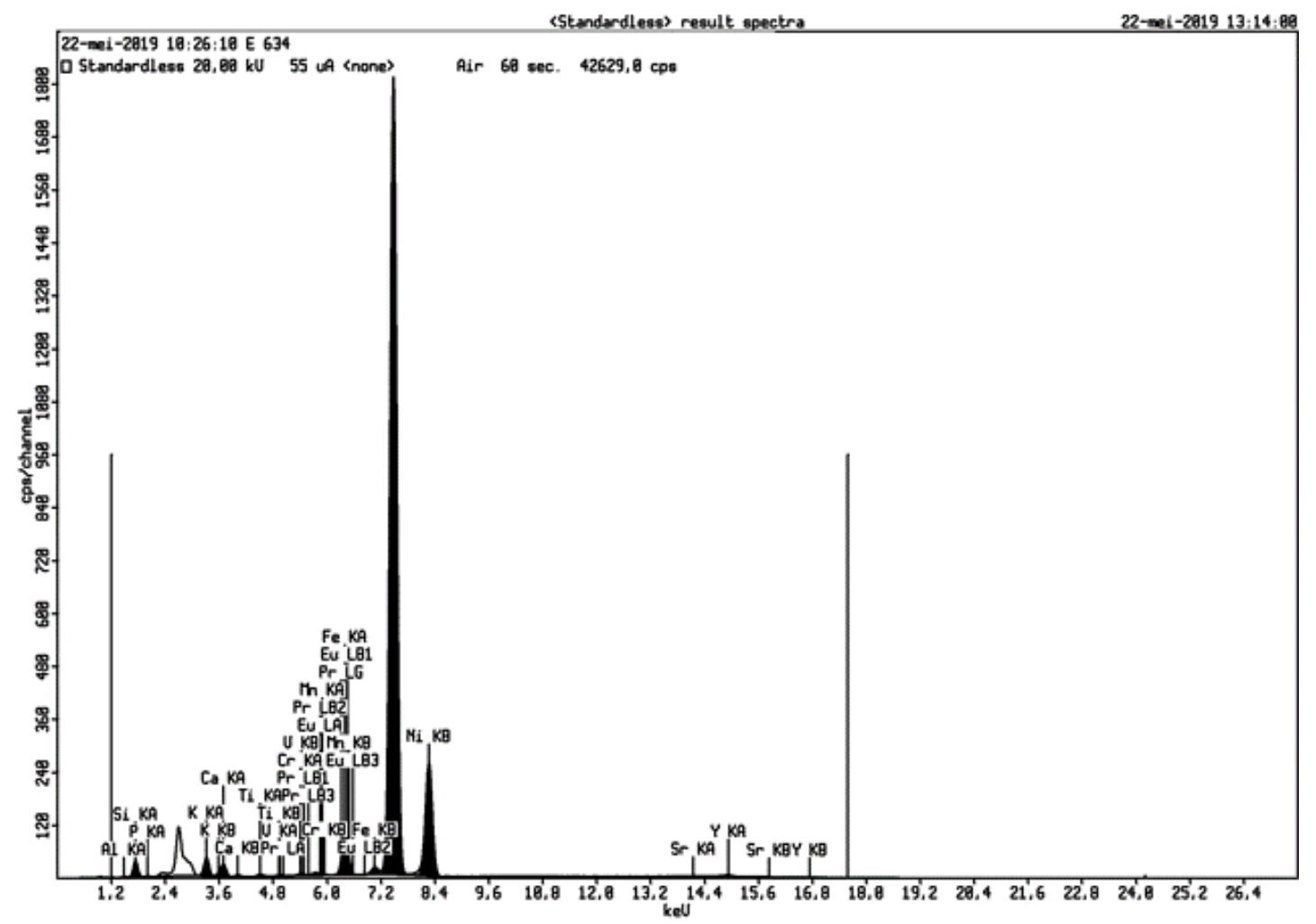

Figure 4. XRF analysis results of the $\mathrm{Ni} /$ zeolite catalyst.

\subsection{Purification of Crude Glycerol}

The purification process was carried out by adding $85 \%$ of $\mathrm{H}_{3} \mathrm{PO}_{4}$ solution into $100 \mathrm{~g}$ of raw glycerol to reach $\mathrm{pH} \pm$ 2.5 and leaving the solution for $\pm 24 \mathrm{~h}$ until 2 phases formed. The glycerol layer was separated from the other layers and was added with distilled water at a volume ratio of 2:3. Activated carbon with a total of $5 \%$ of the total sample volume was added to the solution and was stirred for $30 \mathrm{~min}$. After being allowed to stand for $24 \mathrm{~h}$, then the solution was filtered to separate the activated carbon and analyzed for water and glycerol content. Table 2 shows the characteristics and properties of crude, purified and pro analysis glycerol.

Table 2. Characteristics and Properties of Crude and Purified Glycerol

\begin{tabular}{lccc}
\hline \multicolumn{1}{c}{ Properties } & Crude Glycerol & Purified Glycerol & Glycerol p. a. (Merck) \\
\hline Density $(\mathrm{g} / \mathrm{mL})$ & 1.1619 & 1.233 & 1.262 \\
Viscosity $(\mathrm{mPa} . \mathrm{s})$ & 768 & 926 & 1499 \\
Concentration $(\%)$ & 66.64 & 71.15 & 99.5 \\
Water content $(\%)$ & 16.64 & 1.3 & 0.5 \\
Color & Yellow brownish & Clear yellowish & Clear \\
\hline
\end{tabular}

\subsection{Reaction Procedure and Product Analysis}

The esterification reactions were carried out in a stirred batch reactor equipped with a temperature controller and water condenser (Figure 5). The reactions were performed at a temperature of $100^{\circ} \mathrm{C}$ for $60 \mathrm{~min}$. The acetic acid and glycerol reactants were loaded into the reactor with a moles ratio varying from 3:1, 5:1, 7:1 and 9:1. After the reactor temperature reached at $100^{\circ} \mathrm{C}$, the catalyst was added with a percentage of 1 to $7 \%$ by mass of acetic acid the time reaction reached within $60 \mathrm{~min}$, the reaction was stopped and the sample to be analyzed by titration method to determine the remaining of acetic acid. The remaining unreacted acetic acid was used as a basis for the determination of glycerol conversion. The results of the acetylation reaction were applied by adding it to commercial fuels (premium, pertalite and pertamax) and measuring the octane increase using an analyzer meter Octane Number Portable Tester. 


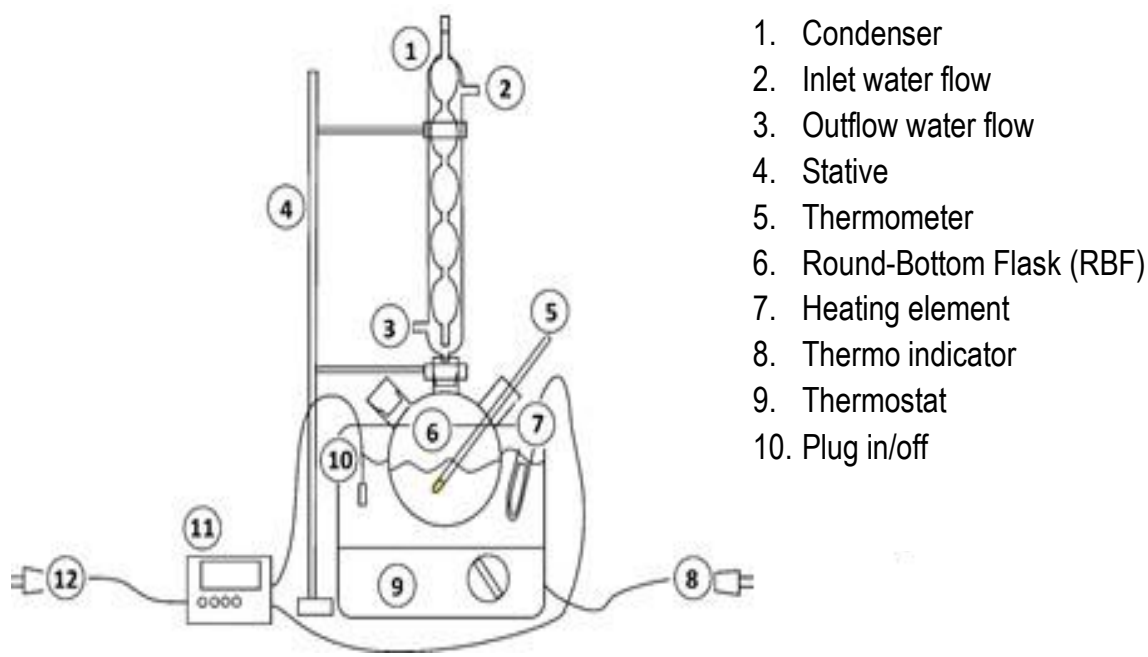

Figure 5. The scheme of esterification reaction equipment.

\section{Result and Discussion}

\subsection{The Effect of Mole Ratio Reactants (Acetic Acid to Glycerol) on Conversion Reaction}

The experiments were carried out with molar ratio reactant of acetic acid to glycerol varying from 3:1, 5:1, 7:1 and 9:1. The ratio between reactants was one of the factors that influenced the equilibrium of reactions in reversible reactions. Excessive reactants causing in equilibrium to shift towards the product so resulted in an increasing of glycerol conversion. As shown in Figure 6, the higher the mole ratio of acetic acid to glycerol, the glycerol conversion also increases. In the mole ratio of reactants between acetic acid and glycerol (3:1) and the concentration of acetic acid catalyst $7 \%$ (by weight) resulted in glycerol conversion of $20.16 \%$, while at ratio of $9: 1$ with catalyst concentration $7 \%$ (by weight), glycerol conversion of $63.9 \%$ was produced, this shows the increasing of mole ratio reactant tend to increase the conversion.

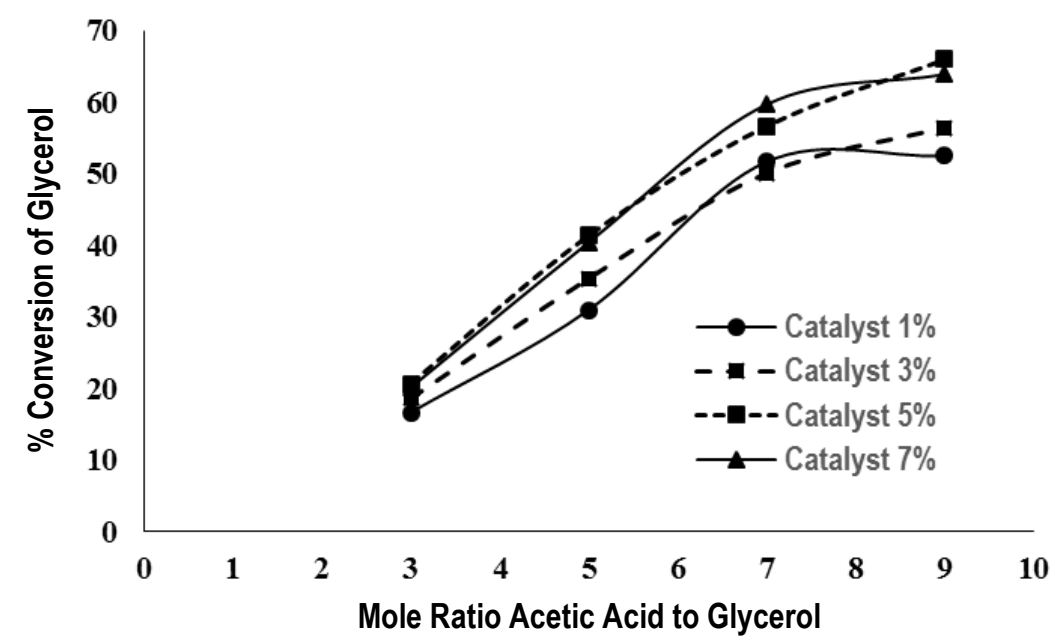

Figure 6 . The relation of glycerol conversion to mole ratio of reactant and catalyst concentration.

In this study, the highest glycerol conversion obtained at the mole ratio of 9 and $5 \%$ catalyst with resulting in glycerol conversion of $66.02 \%$. This result is lower than the research conducted by Rizki et al. [8] using ratio mole of reactant (acetic acid and glycerol) is 7:1 which resulting in glycerol conversion of $96.49 \%$. This is due to the time that research conducted in the esterification process for 240 min because the longer reaction time will result in the higher conversion due to the greater chance of reagent colliding with each other [9]. The same thing was also done by Sari et al. [10] who carried out the reaction with mole ratio reactant of 7 and 240 min of reaction time which result glycerol conversion of $90 \%$. Besides the ratio of reactants, the reaction temperature is one of the factor which influences the rate of reaction. Rizki et al. [8] performed esterification process at temperature of $110^{\circ} \mathrm{C}$ and Widayat et al. [11] doing the esterification at $120^{\circ} \mathrm{C}$ which resulted glycerol conversion of $67.63 \%$. Mufrodi et al. [12] studied the esterified glycerol with acetic acid with a molar ratio of $1: 9$ at a temperature of $1000^{\circ} \mathrm{C}$ using a fly ash catalyst as much as $3 \%$ of the reactant weight and reaction time for $180 \mathrm{~min}$ resulted in glycerol conversion of $53.33 \%$. In general, the esterification reaction is an endothermic reaction where 
increasing in temperature can increase reaction conversion. The increasing temperature will cause the molecular movement to accelerate (collision between reactant molecules increase) and the kinetic energy of the reactant molecules increases. The greater the kinetic energy causes increasing in the rate of reaction and conversion [9].

\subsection{The Effect of Catalyst Concentration on Glycerol Conversion}

Figure 6 shows that the conversion of the reaction tend to increase with increasing the percentage of catalyst to glycerol. These results are consistent with research conducted by Rastegari et al. [13] which states that reaction conversion tends to increase in proportion to the percentage of catalyst concentration. From Figure 6 , it can be seen that the highest conversion is $66.02 \%$ obtained by adding catalyst $5 \%$ by weight of acetic acid the ratio of mole reactants acetic acid and glycerol is $9: 1$. While the addition of catalyst $7 \%$ by weight of acetic acid with the same reactant mole ratio, the conversion is smaller than the addition of $5 \%$ catalyst that is $63.9 \%$. The same thing also happened with the addition of a catalyst of $7 \%$ by weight of acetic acid at a mole ratio of $5: 1$ resulted in a conversion of $40.42 \%$ which was lower than the addition of catalyst $5 \%$ by weight of acetic acid with glycerol conversion of $41.4 \%$ and the addition of a catalyst of $7 \%$ by weight of acetic acid at a mole ratio of $3: 1$ reactants which resulted in a conversion of $20.16 \%$ which was lower than the addition of a catalyst of $5 \%$ by weight of acetic acid with conversion of glycerol $20.66 \%$. This phenomenon may occur because the number of active sites contained in the catalyst is almost sufficient for the maximum amount needed by the reactants. And in the addition of a $7 \%$ by weight catalyst does not result in a perfect mixing due to the large density of the catalyst which is quite large so that the contact area between the catalyst and the reactant has decrease.

\subsection{The Effect of Addition of Bio-additive as an Esterification Product on Fuel Octane Number}

The glycerol derivative product from acetylation reaction can be used as a bio-additive in fuel to increase the octane number [14]. To show the quality of reaction product as a bio-additive, octane number measurements are made by added the product into commercial fuel such as premium, pertalite, and Pertamax fuels and the results are shown in Figure 7. Based on Figure 7, it can be seen that the higher percentage of reaction product added as bio additives tends to increase the octane number of commercial fuels. With the addition of $8 \%$ volume of bio-additives produced from acetylation reaction can increase the octane number of commercial fuel between $6.5-8.5 \%$.

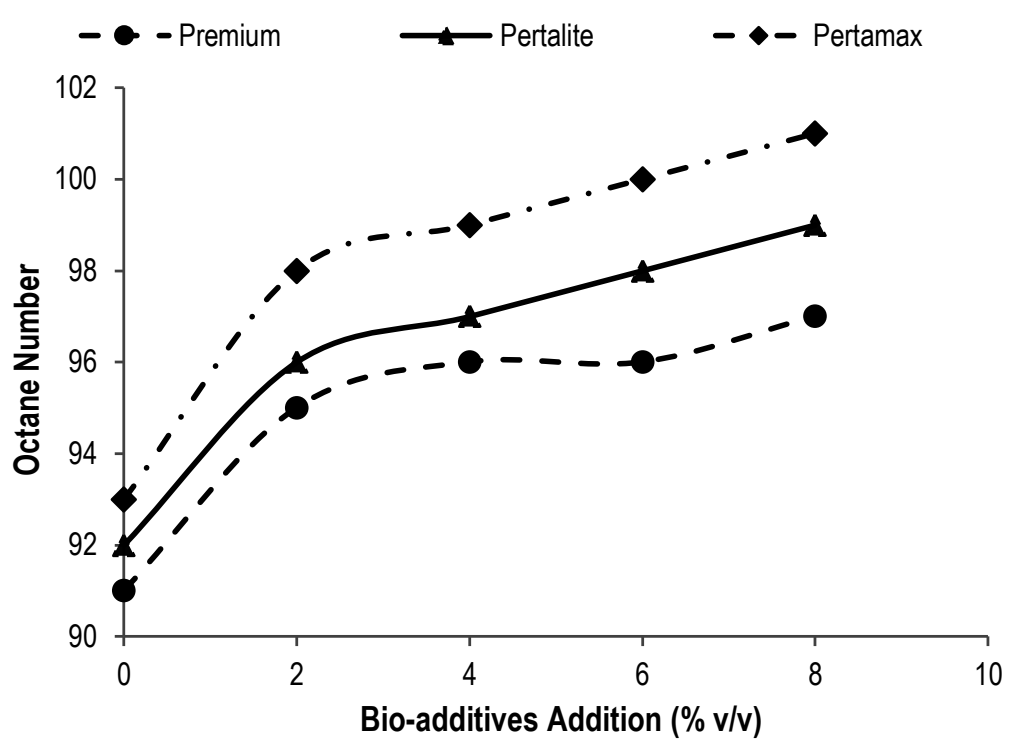

Figure 7. The relation between octane number and percentage of bio-additives addition on commercial fuel.

\section{Conclusion}

Crude glycerol which is a by-product of biodiesel production can be purified using an acidification process with the addition of $\mathrm{H}_{3} \mathrm{PO}_{4}$. The purified glycerol can be converted through acetylation process based on a modified zeolite catalyst into a valueable product namely triacetin which use as a bio-additive to increase the octane number of commercial fuels. The esterification reaction of glycerol with acetic acid (acetylation process) is carried out by varying the mole ratio of reactants (acetic acid to glycerol) and the percentage of catalyst added (\% by weight). Based on the calculation of the reaction conversion of the remaining or unreacted acetic acid the highest reaction conversion of glycerol $(66.02 \%)$ is obtained from a molar ratio of reactants $9: 1$ and catalyst concentration of $5 \%$. In case, the result is added to commercial fuels as bio-additives, it could increase the octane number by $6.5-8.8 \%$. 


\section{References}

[1]. J. A. Melero, R. van Grieken, G. Morales, \& M. Paniagua, "Acidic Mesoporous Silica for the Acetylation of Glycerol: Synthesis of Bioadditives to Petrol Fuel," Energy \& Fuels, vol. 21, no. 3, pp. 1782-1791, 2007.

[2]. Nuryoto, H. Sulistyo, S. S. Rahayu, \& Sutijan, "Kinetika Reaksi Esterifikasi Gliserol dengan Asam Asetat Menggunakan Katalisator Indion 225 Na," Jurnal Rekayasa Proses, vol. 5, no. 2, pp. 35-39, 2011.

[3]. L. Zhou, E. Al-Zaini, \& A. A. Adesina, "Catalytic Characteristics and Parameters Optimization of the Glycerol Acetylation over Solid Acid Catalysts," Fuel, vol. 103, pp. 617-625, 2013.

[4]. P. V. Rao \& B. V. A. Rao, "Effect of Adding Triacetin Additive with Coconut Oil Methyl Ester (COME) in Performance and Emission Characteristics of DI Diesel Engine," International Journal of Thermal Technology, vol. 1, no. 1, pp. 100106, 2011.

[5]. M. T. Razzak, T. Las, \& Priyambodo, "The Characterization of Indonesian's Natural Zeolite for Water Filtration System," Valensi, vol. 3, no. 2, pp. 129-137, 2013.

[6]. N. F. Fatimah \& B. Utami, "Sintesis dan Analisis Spektra IR, Difraktogram XRD, SEM pada Material Katalis Berbahan Ni/zeolit Alam Teraktivasi dengan Metode Impregnasi," Journal Cis-Trans, vol. 1, no. 1, pp. 35-39, 2017.

[7]. S. Kadarwati, F. Rahmawati, P. E. Rahayu, \& K. I. Supardi, "Kinetics and Mechanism of Ni/Zeolite-Catalyzed Hydrocracking of Palm Oil into Bio-Fuel," Indonesian Journal of Chemistry, vol. 13, no. 1, pp. 77-85, 2013

[8]. J. Rizki, Z. Helwani, \& H. Rionaldo, "Pemanfaatan Gliserol dari Produk Samping Biodiesel menjadi Triacetin melalui Proses Esterifikasi Menggunakan Katalis Zeolit Alam," Journal Online Mahasiswa Fakultas Teknik Universitas Riau, vol. 2, no.1, pp. 1-8, 2015.

[9]. O. Levenspiel, Chemical Reaction Engineering, 3th Edition. New York: Wiley and Sons, 1999.

[10]. N. Sari, Z. Helwani, \& H. Rionaldo, "Esterifikasi Gliserol dari Produk Samping Biodiesel menjadi Triasetin Menggunakan Katalis Zeolit Alam," Jurnal Online Mahasiswa Fakultas Teknik Universitas Riau, vol. 2 no. 1, pp. 1-7, 2015.

[11]. Widayat, H. Satriadi, Abdullah, \& I. W. K. Handono, "Proses Produksi Triasetin dari Gliserol dengan Katalis Asam Sulfat," Jurnal Teknik Kimia Indonesia, vol. 11, no. 4, pp. 192-198, 2013.

[12]. Z. Mufrodi, S. Rochmadi, \& A. Budiman, "Effect of Temperature and Catalyst upon Triacetin Production from Glycerol (By-product Biodiesel Production) as Octane Booster," In Proceedings of International Conference on Advances in Renewable Energy Technologies, 2010, pp. 130-134.

[13]. H. Rastegari \& H. S. Ghaziaskar, "From Glycerol as the By-product of Biodiesel Production to Value-added Monoacetin by Continuous and Selective Esterification in Acetic Acid," Journal of Industrial and Engineering Chemistry, vol. 21, pp. 856-861, 2015.

[14]. R. B. Cahyono, Z. Mufrodi, A. Hidayat, \& A. Budiman, "Acetylation of Glycerol for Triacetin Production using Zrnatural Zeolite Catalyst," APRN Journal of Engineering and Applied Sciences, vol. 11, no. 8, pp. 5194-5197, 2016. 